\title{
Differential pharmacology and clinical utility of emerging combination treatments in the management of COPD - role of umeclidinium/vilanterol
}

\author{
This article was published in the following Dove Press journal: \\ International journal of COPD \\ 27 June 2014 \\ Number of times this article has been viewed
}

\author{
Mario Malerba' \\ Jaymin Bhagwanji Morjaria ${ }^{2}$ \\ Alessandro Radaeli ${ }^{3}$ \\ 'Department of Internal Medicine, \\ University of Brescia, Brescia, Italy \\ ${ }^{2}$ Department of Academic Respiratory \\ Medicine, Hull York Medical \\ School, University of Hull, Castle \\ Hill Hospital, Cottingham, United \\ Kingdom; ${ }^{3}$ Department of Emergency, \\ Spedali Civili di Brescia, Brescia, Italy
}

\begin{abstract}
Chronic obstructive pulmonary disease (COPD) is a preventable and treatable disease characterized by airflow limitation that is not fully reversible. Bronchodilator therapy is the cornerstone in COPD treatment. Bronchodilation in COPD is mainly achieved via administration of long- and ultralong-acting $\beta_{2}$-agonists and with long-acting muscarinic antagonists. New combinations of bronchodilators with dual-acting muscarinic antagonist and $\beta_{2}$-agonist properties have been licensed, and others are currently being developed with the aim of achieving once-daily dosing, and therefore may improve the likelihood of treatment compliance. These combination bronchodilators include glycopyrronium bromide/indacaterol maleate, umeclidinium (UMEC) bromide/vilanterol trifenatate (VI), aclidinium bromide/formoterol and tiotropium bromide/olodaterol (Boehringer Ingelheim, Germany). This review will focus mainly on studies and clinical trials involving the novel fixed-dose combination of UMEC/VI at doses of $125 / 25 \mu \mathrm{g}$ and $62.5 / 25 \mu \mathrm{g}$ in patients with COPD. Data from large clinical trials involving more than 4,500 COPD patients indicate that UMEC/VI is an effective once-daily treatment in COPD with improved pulmonary function. Future studies assessing the impact of this combination on exacerbations, delay in disease progression, and health status in patients with COPD are warranted.
\end{abstract}

Keywords: COPD treatment, umeclidinium, vilanterol, bronchodilators combination, long acting beta2-agonists, long acting muscarinic receptor antagonists

\section{Introduction}

The American Thoracic and the European Respiratory Societies define chronic obstructive pulmonary disease (COPD) as a preventable and treatable disease, characterized by airflow limitation that is not fully reversible, in contrast to asthma, where airflow obstruction is usually reversible. ${ }^{1}$ It includes chronic obstructive bronchiolitis involving the small airways, and emphysema that results in destruction of lung parenchyma, loss of lung elasticity, and closure of small airways. These new statements of COPD being preventable and treatable underline the importance of carefully optimizing therapy in COPD patients. With the recent increase in the number of available pharmacological agents, there is more choice, improving the decision-making process in managing COPD patients.

In moderate-to-severe disease and in respiratory impairment, the coadministration of different bronchodilator classes has been demonstrated to be more effective in subjective and objective COPD parameters in comparison with the use of a single drug class. $^{2}$ Bronchodilator treatment in COPD is mainly via administration of long- and
Correspondence: Mario Malerba

Department of Internal Medicine,

University of Brescia and AOU

Spedali Civili, Brescia, Italy

Tel +390303995250

Email malerba@med.unibs.it 
ultralong-acting $\beta_{2}$-agonists (LABAs) and with long-acting muscarinic antagonists (LAMAs). $\beta_{2}$-agonists are sympathomimetic agents that stimulate $\beta_{2}$ receptors in airway cells to produce a variety of effects, mainly smooth muscle relaxation and bronchodilation. ${ }^{3} \beta_{2}$-agonists are classified as short-acting, with a 3-6-hour duration of action, and LABAs have a duration of action $\geq 12$ hours. The difference in onset of action is related to the lipophilicity of each of these agents and their ability to activate the receptor. ${ }^{4}$

The parasympathetic activity in the airways of mediumlarge caliber is mediated through the muscarinic receptors (M1 and M3) and acts on smooth muscle contraction and mucus secretion of airways while the effects on $\mathrm{M} 2$ receptors inhibit acetylcholine release from nerve terminals. Increased cholinergic tone is involved in the pathogenesis of COPD, contributing to both the increase in bronchial smooth muscle tone and mucus hypersecretion. ${ }^{5}$ In fact, anticholinergics reduce airway tone and improve expiratory flow limitation, hyperinflation, and exercise capacity in patients with COPD. With the pivotal role of bronchodilators in the treatment of obstructive airway diseases, there is a relevant interest in finding novel classes of bronchodilator drugs. Currently, new classes of bronchodilators have been discovered, providing impetus to try new associations of LABA and LAMA in addition to inhaled corticosteroid therapy for the long-term treatment of COPD.

New combinations of bronchodilators with dual-acting muscarinic antagonist and $\beta_{2}$-agonist activity are licensed, and others are currently being developed with the aim of achieving once-daily dosing, thereby improving the likelihood of treatment compliance. These include the recently licensed glycopyrronium bromide/indacaterol maleate (QVA149 [Ulitbro ${ }^{\circledR}$ ]; Novartis International AG, Basel, Switzerland) (licensed in Japan and Europe) and umeclidinium bromide/ vilanterol trifenatate (Anoro ${ }^{\circledR}$; GlaxoSmithKline plc, London, UK) (licensed in USA). Other fixed-dose combination inhalers, aclidinium bromide/formoterol (Almirall, Barcelona, Spain) and tiotropium bromide/olodaterol (Boehringer Ingelheim, Ingelheim, Germany), are still being assessed. All four of these combination bronchodilator compounds combine two separate molecules in a single novel dry powder delivery device including the Breezehaler ${ }^{\circledR}$, Ellipta $^{\circledR}$, Genuair $^{\circledR}$, and Respimat ${ }^{\circledR}$, respectively. Another technological advance in the development of combination bronchodilators is the invention of muscarinic receptor antagonist and $\beta_{2}$-adrenoceptor agonist molecules. These compounds have the dual pharmacological activities of LAMA and LABA but are bifunctional molecules with muscarinic antagonistic activity at one end, separated by an inert linker portion from the $\beta_{2}$-agonist at the other end. These molecules are currently in Phase I and II of development and hold great promise for the future.

In this review, we mainly focus on studies and clinical trials involving the novel, fixed-dose combination of vilanterol trifenatate (VI) and umeclidinium (UMEC), UMEC/VI, at doses of $125 / 25 \mu \mathrm{g}$ and $62.5 / 25 \mu \mathrm{g}$ in patients with COPD. The association of UMEC/VI (62.5/25 $\mu \mathrm{g})$ has been newly licensed for once-daily, routine treatment in COPD patients. ${ }^{6}$ Prior to delving into the combination UMEC/VI bronchodilator use in COPD, we briefly summarize the two components.

\section{UMEC characteristics}

UMEC is a novel anticholinergic agent, similar to tiotropium bromide, with a strong affinity to $\mathrm{M} 3$ receptors. It is rapidly absorbed (time to reach maximal concentration $\left[\mathrm{T}_{\max }\right]$, 5-15 minutes) and presents slow functional reversibility at the M3 receptor, hence manifesting faster onset and prolonged duration of action. ${ }^{7}$ Moreover, it is safe, as 1\%-2\% of the total dose is excreted unchanged in the urine $\left(\mathrm{T}_{\max }, 5-15\right.$ minutes $)$ after single and repeat doses, and 1.5-1.9-fold accumulation is observed after repeat dosing. ${ }^{8}$ Single and repeat doses of UMEC were well tolerated and produced clinically relevant 24 hour lung function improvements in patients with COPD. ${ }^{8}$ The dose-response efficacy of once-daily UMEC in moderate-to-severe COPD patients using 125, 250, and $500 \mu \mathrm{g}$ UMEC showed significantly improved forced expiratory volume in 1 second $\left(\mathrm{FEV}_{1}\right)$ versus placebo and was well tolerated. ${ }^{9}$ In another 12 -week study in COPD subjects, besides lung function improvements, patients administered UMEC $62.5 \mu \mathrm{g}$ and $125 \mu \mathrm{g}$ had improved breathlessness symptoms and enhanced health status. ${ }^{10}$

\section{VI characteristics}

VI is a potent, selective $\beta_{2}$-adrenoreceptor agonist with a long duration of action. It has greater potency than indacaterol and salbutamol and greater intrinsic efficacy than salmeterol. ${ }^{11}$ VI has significantly greater selectivity for $\beta_{2}$-adrenoreceptor than formoterol, indacaterol, and albuterol. ${ }^{12,13}$ Moreover, it is a metabolically labile LABA that is converted into metabolites with significantly lower $\beta_{2}$ activity. Following an inhaled dose, VI shows low systemic absorption, ${ }^{14}$ is rapidly absorbed (median $\mathrm{T}_{\text {max }}$ of 10 minutes), and shows no safety issues, especially cardiovascular. ${ }^{15,16}$ A single dose of VI (25-100 $\mu \mathrm{g}$ ) was not only well tolerated in COPD patients, but it was also reported to have a rapid onset ( 5 minutes) and 
prolonged bronchodilation ( 25 hours), hence it was suitable for once-daily administration. ${ }^{17}$ These efficacy and safety endpoints were also confirmed in moderate-to-severe COPD subjects in a 28-day Phase IIb study. ${ }^{18}$

\section{Adverse effects}

UMEC per se, being an anticholinergic, has a good safety and tolerability profile. More recently approved inhaled anticholinergic agents are well tolerated because they are very poorly absorbed following inhalation. Anticholinergic compounds are more commonly associated with the manifestation of dry mouth, constipation, dyspepsia, gastroesophageal reflux, urinary difficulties, papillary dilatation, blurred vision with the possibility of worsening glaucoma symptoms, and paradoxical bronchoconstriction. ${ }^{19-24}$ The latter has been postulated to arise from blockade of prejunctional M2 receptor on airway cholinergic nerves, which normally inhibit acetylcholine release. Of note, alarm has been raised about possible associations of anticholinergics with cardiovascular morbidity and mortality. ${ }^{25}$ However, the UPLIFT trial failed to find an increased risk in mortality or cardiovascular morbidity during treatment in patients with COPD.${ }^{26}$ Controversially, a systematic review and meta-analysis observed that tiotropium administered via the Respimat $^{\circledR}$ preparation was associated with a statistically significant increased risk of mortality, probably related to a greater absorption of tiotropium into the systemic circulation due to the new formulation. ${ }^{27}$ However, this has been disproved in a study of over 17,000 patients conducted more recently. ${ }^{28,29}$

Similarly, VI seems safe and well tolerated; however, being a $\beta_{2}$-agonist, it has potential side effects related to the stimulation of the $\beta$-adrenergic receptor. This is mainly due to the widespread distribution of $\beta_{2}$-adrenoreceptors, which when $\beta_{2}$ agonists are absorbed into the systemic circulation, result in undesired responses. These effects comprise palpitations with heart rate elevation, arrhythmias (particularly supraventricular tachycardias), nervousness, tremor, anxiety, hypokalemia, glycogenolysis and hyperglycemia, and transient airway obstruction. ${ }^{30-34}$

\section{UMEC and VI}

In December 2013, the combination bronchodilator UMEC/ VI $(62.5 / 25 \mu \mathrm{g})$ in a single inhaler was approved in the USA. ${ }^{6}$ The development program for UMEC/VI leading to US Food and Drug Administration (FDA) approval implicated several Phase I studies and four large 24-week pivotal Phase II/III trials. We have summarized the studies discussed in Table 1 with the main endpoints assessed.

\section{Phase I UMEC/VI studies}

UMEC (500 $\mu \mathrm{g})$ and VI (50 $\mu \mathrm{g})$ administered separately and in combination using a novel dry powder inhaler, Ellipta ${ }^{\circledR}$, in 16 healthy Japanese males showed that in all treatment arms, the administered medication was well tolerated. ${ }^{35}$ Pharmacokinetic $(\mathrm{PK})$ evaluation demonstrated rapid absorption $\left(\mathrm{T}_{\max }\right.$ 5 minutes for both) followed by rapid elimination with median $\mathrm{T}_{\text {last }}$ (time to last measurable concentration) of 4-5 hours for UMEC and median $\mathrm{T}_{\text {last }}$ of 1.5-2.0 hours for VI.

In another study by the same group, the effects of 10 days of inhaled UMEC/VI 125/25 $\mu \mathrm{g}$ and 500/100 $\mu \mathrm{g}$ (supratherapeutic dose) and UMEC alone $(500 \mu \mathrm{g})$ on the QT interval (Fridericia's correction [QTcF]) in 103 healthy subjects was compared with placebo and moxifloxacin treatment (positive control). ${ }^{36}$ Although there was no observed difference in QTcF between UMEC/VI or UMEC monotherapy and placebo (while moxifloxacin showed a significant increase in QTcF), treatment with UMEC/VI and UMEC alone were associated with an increase in heart rate compared with placebo. The maximum increase of heart rate was observed 10 minutes postdose, with a rapid normalization. Moreover, $20 \%$ of the participants treated with UMEC/VI $(500 / 100 \mu \mathrm{g})$ reported palpitation without any electrocardiograph abnormalities.

To evaluate the effects of oral administration of verapamil (240 mg), an antiarrhythmic agent frequently used by patients with COPD and cardiovascular related comorbidities, the PK, pharmacodynamics, safety, and tolerability of inhaled UMEC $500 \mu \mathrm{g}$ monotherapy and UMEC/VI 500/25 $\mu \mathrm{g}$ combination therapy has also been conducted. ${ }^{37}$ Administration of UMEC alone and in combination with VI was well tolerated and did not show clinically relevant increases in systemic exposure for either drug.

Two additional studies have excluded significant adverse effects with the use of UMEC/VI in patients with moderate hepatic and severe renal impairment. ${ }^{38,39}$

\section{Phase II UMEC/VI studies}

Feldman et $\mathrm{al}^{40}$ conducted a double-blind, placebo-controlled (DBPC) Phase II study that assessed the safety, tolerability, PK, and pharmacodynamics of inhaled UMEC/VI $(500 / 25 \mu \mathrm{g})(\mathrm{n}=42)$ administered once daily via the Ellipta ${ }^{\circledR}$ inhaler over 28 days compared to placebo $(n=9)$ in subjects with COPD. UMEC/VI was noninferior to placebo for the primary end point: the mean change from baseline in 0-6 hours postdose weighted mean pulse rate after 28 days of treatment. Also, no significant differences were observed in blood pressure, minimum and maximum heart rate, and QTcF 
Table I Characteristics of the clinical studies on UMEC/VI

\begin{tabular}{|c|c|c|c|c|c|}
\hline Reference & Patients & Duration & Treatment arms & $\begin{array}{l}\text { Primary endpoint } \\
\text { Co-primary endpoint }\end{array}$ & Results \\
\hline Kelleher et $\mathrm{al}^{35}$ & 16 (healthy) & Single dose & $\begin{array}{l}\text { UMEC/VI }(500 / 50 \mu \mathrm{g}) \\
\text { UMEC }(500) \\
\text { VI }(50) \\
\text { Placebo }\end{array}$ & Safety & $\begin{array}{l}\text { No differences of active } \\
\text { treatments vs placebo }\end{array}$ \\
\hline Kelleher et $\mathrm{al}^{36}$ & 103 (healthy) & 28 days & $\begin{array}{l}\text { UMEC/VI }(125 / 25 \mu \mathrm{g}) \\
\text { UMEC/VI }(500 / 100 \mu \mathrm{g}) \\
\text { UMEC }(500 \mu \mathrm{g}) \\
\text { Moxifloxacin* } \\
\text { Placebo }\end{array}$ & Safety & $\begin{array}{l}\text { No differences of active } \\
\text { treatments vs placebo }\end{array}$ \\
\hline Feldman et $\mathrm{al}^{40}$ & $5 \mathrm{I}(\mathrm{COPD})$ & 28 days & $\begin{array}{l}\text { UMEC/VI }(500 / 25 \mu \mathrm{g}) \mathrm{n}=42 \\
\text { Placebo } \mathrm{n}=9\end{array}$ & $\begin{array}{l}\text { Weighted mean pulse } \\
\text { rate over } 0-6 \text { hours at day } 28\end{array}$ & $\begin{array}{l}\text { Weighted mean pulse rate: } \\
\text { UMEC/VI was non inferior to } \\
\text { placebo } \\
\text { FEV, mean change from } \\
\text { baseline } 163 \mathrm{~mL} \text { vs } 9 \mathrm{~mL} \\
\text { (active vs placebo) }\end{array}$ \\
\hline Donohue et $\mathrm{a}^{41}$ & I532 (COPD) & 24 weeks & $\begin{array}{l}\text { UMEC/VI }(62.5 / 25 \mu g) n=413 \\
\text { UMEC }(62.5 \mu g) n=4 \mid 2 \\
\text { VI }(25 \mu g) n=4 \mid 8 \\
\text { Placebo } n=208\end{array}$ & $\begin{array}{l}\text { Trough FEV, at day } 169 \\
\text { (Week } 24 \text { ) } \\
0 \text { to } 6 \text { hours weighted } \\
\text { mean FEV, at day } 168\end{array}$ & $\begin{array}{l}\text { All active improved FEV, vs } \\
\text { placebo } \\
\text { Improvement RM, TDI, } \\
\text { HRQLQ combined treatment } \\
\text { compared to placebo }\end{array}$ \\
\hline Celli et $\mathrm{al}^{42}$ & I 493 (COPD) & 24 weeks & $\begin{array}{l}\text { UMEC/VI }(125 / 25 \mu g) n=403 \\
\text { UMEC }(I 25 \mu g) n=407 \\
\text { VI }(25 \mu g) n=404 \\
\text { Placebo } n=275\end{array}$ & $\begin{array}{l}\text { Trough FEV, at day } 169 \\
\text { (Week } 24 \text { ) } \\
0 \text { to } 6 \text { hours weighted } \\
\text { mean } F E V_{\text {, }} \text { at day } 168\end{array}$ & $\begin{array}{l}\text { All active improved FEV, vs } \\
\text { placebo } \\
\text { Improvement RM, TDI, } \\
\text { HRQLQ combined treatment } \\
\text { compared to placebo }\end{array}$ \\
\hline Anzueto et $\mathrm{al}^{43}$ & 843 (COPD) & 24 weeks & $\begin{array}{l}\text { UMEC/VI }(I 25 / 25 \mu \mathrm{g}) \mathrm{n}=2 \mathrm{I} 4 \\
\text { UMEC/VI }(62.5 / 25 \mu \mathrm{g}) \mathrm{n}=2 \mathrm{I} 2 \\
\text { VI }(25 \mu \mathrm{g}) \mathrm{n}=208 \\
\text { TIO }(18 \mu \mathrm{g}) \mathrm{n}=207\end{array}$ & $\begin{array}{l}\text { Trough FEV, at day } 169 \\
\text { (Week } 24 \text { ) } \\
0 \text { to } 6 \text { hours weighted } \\
\text { mean } \mathrm{FEV} \text {, at day } 168\end{array}$ & $\begin{array}{l}\text { Improvements in least squares } \\
\text { mean change from baseline } \\
\mathrm{FEV} \text {, and } 0-6 \text { hours weighted } \\
\text { mean } \mathrm{FEV} \text {, both combination } \\
\text { treatments compared with } \\
\text { the monotherapies }\end{array}$ \\
\hline NCT0131691344 & 869 (COPD) & 24 weeks & $\begin{array}{l}\text { UMEC/VI }(125 / 25 \mu \mathrm{g}) \mathrm{n}=215 \\
\text { UMEC/VI }(62.5 / 25 \mu \mathrm{g}) \mathrm{n}=217 \\
\text { UMEC }(125 \mu \mathrm{g}) \mathrm{n}=222 \\
\text { TIO }(18 \mu \mathrm{g}) \mathrm{n}=215\end{array}$ & $\begin{array}{l}\text { Trough FEV, at day } 169 \\
\text { (Week 24) } \\
0 \text { to } 6 \text { hours weighted } \\
\text { mean FEV, at day } 168\end{array}$ & $\begin{array}{l}\text { UMEC/VI (both doses) } \\
\text { improved FEV, vs TIO }\end{array}$ \\
\hline
\end{tabular}

Note: *Treatment arms description not provided.

Abbreviations: COPD, chronic obstructive pulmonary disease; UMEC, umeclidinium; VI, vilanterol; TIO, tiotropium; FEV RM, rescue medication; TDI, transient dyspnea index; HRQLQ, health related quality of life questionnaire.

between the two treatment groups. Eleven (26\%) patients reported adverse events in the UMEC/VI group compared to one patient in the placebo group; however, no serious adverse events were reported in either treatment groups. PK results confirmed rapid absorption (median $\mathrm{T}_{\text {max }} \sim 6$ minutes for both drugs), followed by a rapid decline in plasma concentrations, indicating rapid distribution and elimination of both drugs, with no evidence of accumulation.

Donohue et $\mathrm{al}^{41}$ conducted a DBPC randomized, parallelgroup study for the evaluation of the efficacy and safety of 24-week treatment with once-daily UMEC/VI (62.5/25 $\mu \mathrm{g})$ compared with UMEC $62.5 \mu \mathrm{g}$ and VI $25 \mu \mathrm{g}$ monotherapies in 1,532 patients with moderate-to-severe COPD. All treatment groups resulted in significant improvements in trough $\mathrm{FEV}_{1}$ versus placebo $(72-167 \mathrm{~mL}$; all $P<0.001)$, but increases with UMEC/VI combination was greater than that observed with monotherapies $(52-95 \mathrm{~mL}$; all $P \leq 0.004)$. Compared to placebo, UMEC/VI was associated with improved rescue medication use, transition dyspnea index (TDI), health-related quality of life questionnaires compared to placebo. No significant changes in vital signs, electrocardiography, or laboratory parameters were noted.

\section{Phase III UMEC/VI studies}

In a Phase III DBPC parallel-group 24-week study, the efficacy and safety of once-daily UMEC/VI $(125 / 25 \mu \mathrm{g})$ was compared to its component monotherapies and placebo in 1,493 patients with COPD. ${ }^{42}$ All the active treatments resulted in significantly improved trough $\mathrm{FEV}_{1}$ versus placebo (124-238 mL; all $P<0.001$ ); in fact, the combination therapy 
resulted in significantly greater functional benefit compared to the monotherapy-treated arms of the study $(79-114 \mathrm{~mL}$; all $P<0.001)$. Additionally, UMEC/VI combination treatment showed improvements in the TDI, rescue medication use, and health-related quality of life. The study did not report any safety concerns, and the numbers of adverse events were similar across all study arms.

The UMEC/VI 125/25 $\mu \mathrm{g}$ and 62.5/25 $\mu \mathrm{g}$ combinations have been compared with tiotropium $(18 \mu \mathrm{g})$ and VI alone $(25 \mu \mathrm{g})$ in a randomized, double-blind, active-controlled 24-week study involving 843 COPD patients. ${ }^{43}$ Significant improvements in least squares mean change from baseline trough $\mathrm{FEV}_{1}$ and $0-6$ hours weighted mean $\mathrm{FEV}_{1}$ was observed with both combination treatments compared with the monotherapies $(P<0.005)$.

In another randomized, double-blind, active-controlled 24-week study in 869 COPD patients, the combination of UMEC/VI (125/25 $\mu \mathrm{g}$ and 62.5/25 $\mu \mathrm{g})$ was compared with tiotropium $(18 \mu \mathrm{g})$ and UMEC alone $(125 \mu \mathrm{g}){ }^{44}$ Treatment with UMEC/VI 125/25 $\mu \mathrm{g}$ resulted in a statistically significant improvement in trough $\mathrm{FEV}_{1}$ at day 169 compared with tiotropium $(P=0.003)$ but not UMEC $125 \mu \mathrm{g}(P=0.142)$. An improvement was also observed with UMEC/VI $62.5 / 25 \mu \mathrm{g}$ versus tiotropium $(P=0.018)$ but not versus UMEC $125 \mu \mathrm{g}(P=0.377)$.

\section{Efficacy data}

In all the Phase III placebo-controlled studies following 24-weeks treatment, trough $\mathrm{FEV}_{1}$ was significantly higher with both doses of UMEC/VI (62.5/25 $\mu \mathrm{g}$ and 125/25 $\mu \mathrm{g})$ when compared with UMEC alone, VI alone, and placebo (Figure 1). ${ }^{41,42}$ When both doses of UMEC/VI were compared with tiotropium and VI, a significant improvement in trough $\mathrm{FEV}_{1}$ was observed at day 169 and later (Figure 2). ${ }^{43}$
Interestingly, in a yet to be published trial, the preliminary data indicate that the comparison of UMEC/VI 125/25 $\mu \mathrm{g}$ and UMEC $125 \mu \mathrm{g}$ with respect to trough $\mathrm{FEV}_{1}$ was not statistically significant (Figure 3$).{ }^{44}$ Statistically significant improvements in 0-6 hours postdose weighted mean $\mathrm{FEV}_{1}$ were also observed for UMEC/VI (62.5/25 $\mu \mathrm{g}$ and $125 / 25 \mu \mathrm{g}$ doses) over VI and tiotropium. ${ }^{43}$

Additional findings in several Phase III studies showed that treatment with UMEC/VI was associated with significant improvements in some patient-centered secondary outcomes, like TDI, St George's Respiratory Questionnaire (SGRQ) score, rescue albuterol use, and time to first COPD exacerbation. ${ }^{41,42}$ Moreover, both $125 / 25 \mu \mathrm{g}$ and $62.5 / 25 \mu \mathrm{g}$ UMEC/VI doses had significantly more patients achieving the minimal clinical important difference in TDI $(P<0.001)$.

The incidence of COPD exacerbations observed during the studies was lower in UMEC/VI-treated patients compared with placebo ( $8 \%$ versus $14 \%) .{ }^{41,42}$ Moreover, patients on UMEC/VI had a lower risk of exacerbation versus placebo in the analysis of time to first exacerbation. However, it must be considered that the cited studies were not properly designed to measure exacerbations as a primary outcome, and all studies and data need to be considered for longer periods.

\section{Safety data}

Phase I and II studies have not revealed any significant adverse events in patients treated with the combination UMEC/VI at all considered dosages $(125 / 25 \mu \mathrm{g}$ and $62.5 / 25 \mu \mathrm{g})$. One study in particular analyzed the effects of a supratherapeutic dose $(500 / 125 \mu \mathrm{g})$, observing only the occurrence of transient palpitations. ${ }^{35}$ No clinically significant treatmentrelated modification in vital signs, electrocardiogram, or clinical laboratory parameters were observed for UMEC/VI

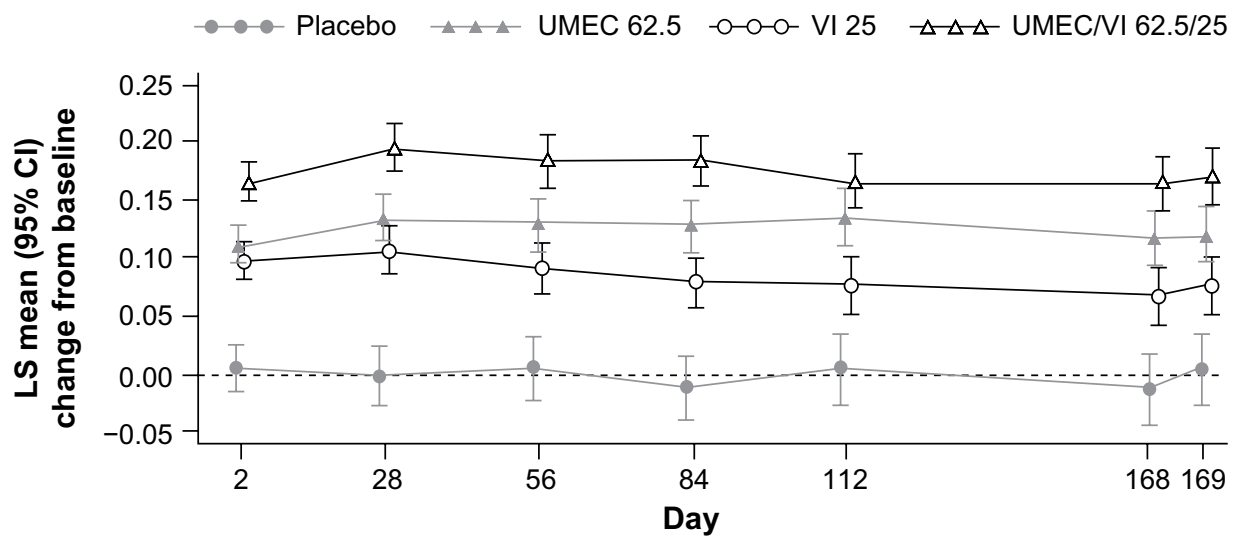

Figure I Least squares mean $(95 \% \mathrm{Cl})$ change from baseline for trough $\mathrm{FEV}_{1}$.

Notes: Reprinted from Respir Med, I07, Donohue JF, Maleki-Yazdi MR, Kilbride S, Mehta R, Kalberg C, Church A, Efficacy and safety of once-daily umeclidinium/vilanterol 62.5/25 mcg in COPD, pages 1538-1546..1 Copyright () 2013, with permission from Elsevier. Placebo not drawn.

Abbreviations: $\mathrm{Cl}$, confidence interval; $\mathrm{FEV}_{1}$, forced expiratory volume in I second; LS, least squares; UMEC, umeclidinium; VI, vilanterol. 


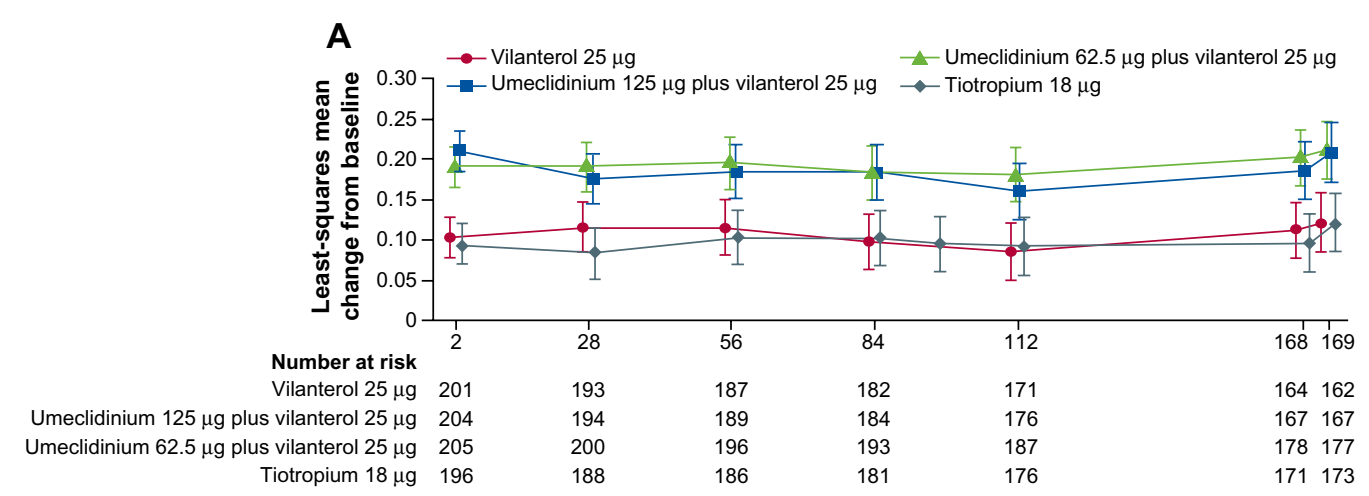

Figure 2 Least squares mean $(95 \% \mathrm{Cl})$ change from baseline for trough $\mathrm{FEV}$, in the treatment arms.

Note: Reprinted from Lancet Respir Med, 2, Decramer M, Anzueto A, Kerwin E, et al, Efficacy and safety of umeclidinium plus vilanterol versus tiotropium, vilanterol, or umeclidinium monotherapies over 24 weeks in patients with chronic obstructive pulmonary disease: results from two multicentre, blinded, randomised controlled trials, pages $472-486 .{ }^{43}$ Copyright (C) 2014, with permission from Elsevier.

Abbreviations: $\mathrm{Cl}$, confidence interval; $\mathrm{FEV}_{1}$, forced expiratory volume in I second.

compared with placebo. A 52-week safety Phase III study was also very recently completed but not yet published or presented. ${ }^{45}$ In this study, the most common adverse events reported were headache and nasopharyngitis. However, the FDA approbation includes a warning on the use of UMEC/VI in patients with cardiovascular disease and has recommended postmarketing studies to better assess safety of the drug combination. ${ }^{6}$ The FDA has included paradoxical bronchospasm, cardiovascular effects, acute narrow-angle glaucoma, and worsening of urinary retention as serious adverse effects. ${ }^{6}$ More importantly, the drug carries a boxed warning stating that LABAs raise the risk for asthma-related death. ${ }^{6}$ In fact, the safety and efficacy of the UMEC/VI combination have not been studied in patients with asthma, and hence is not approved for asthma treatment. It is also not proposed to be used as a rescue therapy for sudden bronchospasm.

\section{Clinical perspectives}

Currently, UMEC/VI (62.5/25 $\mu \mathrm{g})$ combination bronchodilator is the only licensed therapy for use in COPD in the USA and is awaiting approval in other countries.

GOLD 2014 practice guidelines recommend the use of a LAMA or a LABA for symptom relief in patients with stable, relatively milder disease (GOLD stage A or B). ${ }^{2}$ To maximize

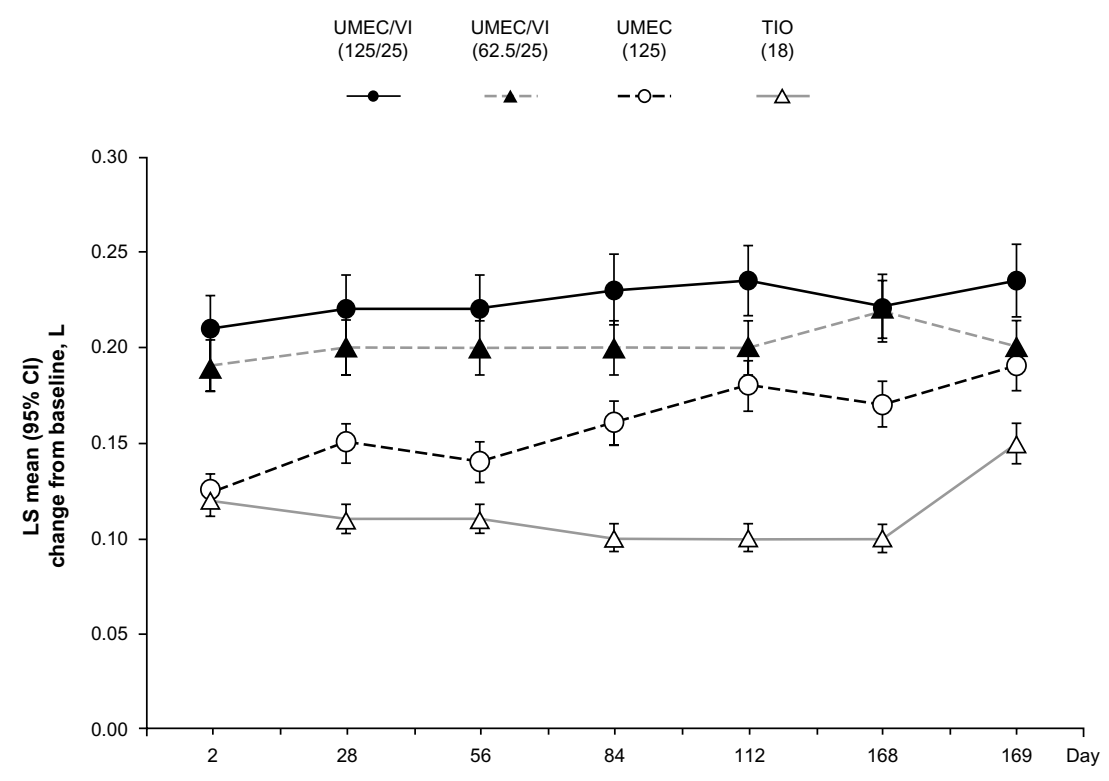

Figure 3 Least squares mean $(95 \% \mathrm{Cl})$ change from baseline for trough $\mathrm{FEV}$, in the treatment arms.

Note: Data from FDA Advisory Committee Briefing Document. ANORO ${ }^{\text {TM ELLIPTA }}{ }^{\text {TM }}$ (Umeclidinium Bromide/Vilanterol Inhalation Powder) For Treatment of Chronic Obstructive Pulmonary Disease. Available from: http://www.fda.gov/downloads/AdvisoryCommittees/CommitteesMeetingMaterials/Drugs/Pulmonary-AllergyDrugsAdvisoryCommittee/ UCM3674I4.pdf. ${ }^{46}$ Accessed May 28, 2014.

Abbreviations: $\mathrm{Cl}$, confidence interval; $\mathrm{FEV}_{1}$, forced expiratory volume in I second; LS, least squares; TIO, tiotropium; UMEC, umeclidinium; VI, vilanterol; FDA, US Food and Drug Administration. 
the effects of bronchodilation in patients with COPD not well controlled with long-acting bronchodilator therapy, adding a molecule with an alternative mechanism of action to bronchodilator activity is the preferred recommendation by various guidelines. In particular, guidelines suggest the use of dual therapy LAMA/LABA treatment alternative for patients in GOLD stage B-D. The combination of two classes of bronchodilators may not only improve lung function, but also lower the risk of adverse effects compared to increasing the dose of a single bronchodilator.

However, the measurement of $\mathrm{FEV}_{1}$ alone may not adequately reflect the overall health of a patient. Evidence suggests that the association of LAMA/LABA show greater improvements in patient-centered outcomes, such as dyspnea symptoms, use of rescue medications, and quality of life, compared to the drugs used individually. Moreover, the combination of LAMA/LABA was seen to better prevent exacerbations of COPD compared to monotherapy.

As discussed, the development of a new combination product relies on the development of the individual ingredient components. The selection of an appropriate dose and dosing frequency for each component is impacted by safety concerns specific to each drug class. LAMA and LABA bronchodilators cause smooth muscle relaxation in the airways, leading to airway expansion and improved lung function. UMEC and VI are intended as maintenance treatment to relieve the symptoms associated with COPD. In the clinical trials mentioned above, UMEC and VI were administered once daily in a single-dose dry powder, inhaled via a novel delivery device at $62.5 \mu \mathrm{g}$ or $125 \mu \mathrm{g}$ and $25 \mu \mathrm{g}$, respectively.

There was strong statistical evidence of beneficial effects of both UMEC/VI 62.5/25 $\mu \mathrm{g}$ and $125 / 25 \mu \mathrm{g}$ as compared to placebo, with respect to the primary and secondary endpoints, in addition to supportive trends across a range of other spirometric and nonspirometric endpoints of interest. However, it is important to note that there was evidence of superiority against placebo for the proposed 62.5/25 $\mu \mathrm{g}$ dose of the combination product from only one published primary efficacy study. ${ }^{41}$ Overall, the combination of UMEC/VI has been reported to be safe and well tolerated, besides being effective in improving lung function and symptoms, in clinical studies of over 4,500 patients with COPD.

COPD guidelines underline the concept of adherence to treatment as a cornerstone in the treatment of COPD, especially because the lack of adherence to therapy is common in these patients given the high frequency of comorbidities, often the advanced age, and the presence of complex multiple treatments. It is known that patients' adherence was robustly related with dosing frequency. ${ }^{31}$ Therefore once-daily dosing should be a strategic weapon to improve adherence. In this perspective, the development of combination treatment such as UMEC/VI could be of great interest to the health community. With this concept in mind, a number of novel monotherapy LAMAs and LABAs, as well as combination bronchodilators, are in development, some in innovative delivery devices (Morjaria, unpublished data, 2014). ${ }^{47}$ These would not only add to the armamentarium of therapies for this debilitating condition, but also provide patients much-needed therapeutic alternatives, which have been previously lacking.

We are aware of the important effects of this combination on respiratory functional parameters; however, we are still lacking important data concerning the frequency of exacerbations, hospitalizations, and mortality of COPD patients. Moreover, new guidelines underline that symptoms and not just airflow limitation now have to be taken into account to guide the management of COPD. ${ }^{48,49}$ Although the combination of UMEC/VI has demonstrated good efficacy and safety in trials conducted to date, studies assessing the impact of this combination on exacerbations, delay in disease progression, and health status in patients with COPD are still needed. Also, evaluations of comparisons between UMEC/VI and new LAMA and LABA compounds will be mandatory before deciding the indication for these new drugs in the treatment for COPD.

\section{Disclosure}

MM has received honoraria for speaking, and financial support to attend meetings/advisory board meetings from Chiesi, GlaxoSmithKline/Allen and Hanburys, and Mundipharma. JBM has received honoraria for speaking, and financial support to attend meetings/advisory board meetings from Wyeth, Chiesi, Pfizer, Merck Sharp and Dohme, Boehringer-Ingelheim, Teva, GlaxoSmithKline/Allen and Hanburys, Napp, Almirall, and Novartis. AR reports no conflicts of interest in this work.

\section{References}

1. Qaseem A, Wilt TJ, Weinberger SE, et al; American College of Physicians; American College of Chest Physicians; American Thoracic Society; European Respiratory Society. Diagnosis and management of stable chronic obstructive pulmonary disease: a clinical practice guideline update from the American College of Physicians, American College of Chest Physicians, American Thoracic Society, and European Respiratory Society. Ann Intern Med. 2011;155(3):179-191.

2. Global Inititaive for Obstructive Lung Disease [homepage on the Internet]. Global strategy for the diagnosis, management and prevention of COPD; 2011 [updated Jan 2014]. Available from: http://www goldcopd.org/guidelines-global-strategy-for-diagnosis-management. html. Accessed May 18, 2014. 
3. Donohue JF, Ohar JA. Bronchodilator therapy of airway disease. In: Chung KF, Barnes PJ, editors. Pharmacology and Therapeutics of Airway Disease. New York: Informa Healthcare USA; 2009:198-225.

4. Ohar JA, Donohue JF. Mono- and combination therapy of long-acting bronchodilators and inhaled corticosteroids in advanced COPD. Semin Respir Crit Care Med. 2010;31(3):321-333.

5. Gross NJ, Co E, Skorodin MS. Cholinergic bronchomotor tone in COPD. Estimates of its amount in comparison with that in normal subjects. Chest. 1989;96(5):984-987.

6. US Food and Drug Administration. FNA News Release. December 18, 2013. Available from: http://www.fda.gov/newsevents/newsroom/ pressannouncements/ucm379057.htm. Accessed May 18, 2014.

7. Salmon M, Luttmann MA, Foley JJ, et al. Pharmacological characterization of GSK573719 (umeclidinium): a novel, long-acting, inhaled antagonist of the muscarinic cholinergic receptors for treatment of pulmonary diseases. J Pharmacol Exp Ther. 2013;345(2):260-270.

8. Tal-Singer R, Cahn A, Mehta R, et al. Initial assessment of single and repeat doses of inhaled umeclidinium in patients with chronic obstructive pulmonary disease: two randomised studies. Eur J Pharmacol. 2013;701(1-3):40-48.

9. Decramer M, Maltais F, Feldman G, et al. Bronchodilation of umeclidinium, a new long-acting muscarinic antagonist, in COPD patients. Respir Physiol Neurobiol. 2013;185(2):393-399.

10. Trivedi R, Richard N, Mehta R, Church A. Umeclidinium in patients with COPD: a randomised, placebo-controlled study. Eur Respir J. 2014;43(1):72-81.

11. Malerba M, Radaeli A, Morjaria JB. Therapeutic potential for novel ultra long-acting $\beta 2$-agonists in the management of COPD: biological and pharmacological aspects. Drug Discov Today. 2012;17(9-10): 496-504.

12. Barrett VJ, Emmons A, Ford AJ, Knowles R. In vitro pharmacological characterisation of GW642444, a novel long acting $\beta 2$-agonist (LABA) using human recombinant $\beta 1 / 2 / 3$ adrenoceptor cAMP assays [Abstract]. Am J Respir Crit Care Med. 2010;181:A4451.

13. Procopiou PA, Barrett VJ, Bevan NJ, et al. Synthesis and structureactivity relationships of long-acting beta2 adrenergic receptor agonists incorporating metabolic inactivation: an antedrug approach. $\mathrm{J} \mathrm{Med}$ Chem. 2010;53(11):4522-4530.

14. Ford AJ, Hughes S, Smith C, Somers G, Ranshaw L. The therapeutic index of vilanterol trifenatate [Abstract]. Eur Respir J. 2010;24:208s.

15. Kempsford R, Norris V, Siederer S. GW642444, a novel inhaled long-acting $\beta 2$ adrenoceptor agonist (LABA), at single doses of 25, 50 and $100 \mathrm{mcg}$, is well tolerated and demonstrates prolonged bronchodilation in asthmatic patients [Abstract]. Am J Respir Crit Care Med. 2010;181:A5413.

16. Kempsford R, Norris V, Siederer S. GW642444, a novel inhaled long-acting $\beta 2$ adrenoceptor agonist (LABA), at single doses of 25, 50 and $100 \mathrm{mcg}$, is well tolerated and demonstrates prolonged bronchodilation in COPD patients [Abstract]. Am J Respir Crit Care Med. 2010;181:A4447.

17. Kempsford R, Norris V, Siederer S. Vilanterol trifenatate, a novel inhaled long-acting beta 2 adrenoceptor agonist, is well tolerated in healthy subjects and demonstrates prolonged bronchodilation in subjects with asthma and COPD. Pulm Pharmacol Ther. 2013;26(2):256-264.

18. Hanania NA, Feldman G, Zachgo W, et al. The efficacy and safety of the novel long-acting $\beta 2$ agonist vilanterol in patients with COPD: a randomized placebo-controlled trial. Chest. 2012;142(1):119-127.

19. Kesten S, Celli B, Decramer M, Leimer I, Tashkin D. Tiotropium HandiHaler in the treatment of COPD: a safety review. Int J Chron Obstruct Pulmon Dis. 2009;4:397-409.

20. Kizer KM, Bess DT, Bedford NK. Blurred vision from ipratropium bromide inhalation. Am J Health Syst Pharm. 1999;56(9):914.

21. Mulpeter KM, Walsh JB, O’Connor M, O’Connell F, Burke C. Ocular hazards of nebulized bronchodilators. Postgrad Med J. 1992;68(796): 132-133.

22. Pras E, Stienlauf S, Pinkhas J, Sidi Y. Urinary retention associated with ipratropium bromide. DICP. 1991;25(9):939-940.
23. Stephenson A, Seitz D, Bell CM, et al. Inhaled anticholinergic drug therapy and the risk of acute urinary retention in chronic obstructive pulmonary disease: a population-based study. Arch Intern Med. 2011;171(10):914-920.

24. Mann JS, Howarth PH, Holgate ST. Bronchoconstriction induced by ipratropium bromide in asthma: relation to hypotonicity. Br Med J (Clin Res Ed). 1984;289(6443):469.

25. Lee TA, Pickard AS, Au DH, Bartle B, Weiss KB. Risk for death associated with medications for recently diagnosed chronic obstructive pulmonary disease. Ann Intern Med. 2008;149(6):380-390.

26. Tashkin DP, Celli B, Senn S, et al; UPLIFT Study Investigators. A 4-year trial of tiotropium in chronic obstructive pulmonary disease. N Engl J Med. 2008;359(15):1543-1554.

27. Singh S, Loke YK, Enright PL, Furberg CD. Mortality associated with tiotropium mist inhaler in patients with chronic obstructive pulmonary disease: systematic review and meta-analysis of randomised controlled trials. BMJ. 2011;342:d3215.

28. Wise RA, Anzueto A, Calverley P, et al. The Tiotropium Safety and Performance in Respimat Trial (TIOSPIR), a large scale, randomized, controlled, parallel-group trial-design and rationale. Respir Res. 2013;14:40.

29. Wise RA, Anzueto A, Cotton D, et al; TIOSPIR Investigators. Tiotropium Respimat inhaler and the risk of death in COPD. $N$ Engl J Med. 2013;369(16):1491-1501.

30. Tashkin DP, Fabbri LM. Long-acting beta-agonists in the management of chronic obstructive pulmonary disease: current and future agents. Respir Res. 2010;11:149.

31. Knudson RJ, Constantine HP. An effect of isoproterenol on ventilation-perfusion in asthmatic versus normal subjects. $J$ Appl Physiol. 1967;22(3):402-406.

32. Wagner PD, Dantzker DR, Iacovoni VE, Tomlin WC, West JB. Ventilation-perfusion inequality in asymptomatic asthma. Am Rev Respir Dis. 1978;118(3):511-524.

33. Philipson LH. Beta-agonists and metabolism. J Allergy Clin Immunol. 2002;110(Suppl 6):S313-S317.

34. Tesfamariam B, Waldron T, Seymour AA. Quantitation of tremor in response to beta-adrenergic receptor stimulation in primates: relationship with hypokalemia. J Pharmacol Toxicol Methods. 1998;40(4): 201-205.

35. Kelleher DL, Mehta RS, Jean-Francois BM, et al. Safety, tolerability, pharmacodynamics and pharmacokinetics of umeclidinium and vilanterol alone and in combination: a randomized crossover trial. PLoS One. 2012;7(12):e50716.

36. Kelleher D, Tombs L, Crater G, Preece A, Brealey N, Mehta R. A placebo- and moxifloxacin-controlled thorough QT study of umeclidinium monotherapy and umeclidinium/vilanterol combination in healthy subjects [Abstract]. Am J Respir Crit Care Med. 2013;187: A1487.

37. Mehta R, Kelleher D, Preece A, Hughes S, Crater G. Effect of verapamil on systemic exposure and safety of umeclidinium and vilanterol: a randomized and open-label study. Int J Chron Obstruct Pulmon Dis. 2013;8:159-167.

38. Mehta R, Hardes K, Kelleher D, Preece A, Tombs L, Brealey N. Effect of moderate hepatic impairment (MHI) on umeclidinium (UMEC) and vilanterol (VI) pharmacokinetics (PK) [Abstract]. Eur Respir J. 2013;42:Suppl 57; A3641.

39. Kelleher D, Hardes K, Brealey N, Tombs L, Preece A, Mehta R. Effect of severe renal impairment (SRI) on umeclidinium (UMEC) and vilanterol (VI) pharmacokinetics (PK) [Abstract]. Eur Respir J. 2013;42:Suppl 57; P4148.

40. Feldman G, Walker RR, Brooks J, Mehta R, Crater G. 28-Day safety and tolerability of umeclidinium in combination with vilanterol in COPD: a randomized placebo-controlled trial. Pulm Pharmacol Ther. 2012;25(6):465-471.

41. Donohue JF, Maleki-Yazdi MR, Kilbride S, Mehta R, Kalberg C, Church A. Efficacy and safety of once-daily umeclidinium/vilanterol 62.5/25 mcg in COPD. Respir Med. 2013;107(10):1538-1546. 
42. Celli BR, Crater G, Kilbride S, et al. A 24-week randomized, doubleblind, placebo-controlled study of the efficacy and safety of once-daily umeclidinium/vilanterol 125/25 mcg in COPD [Abstract]. Am J Respir Crit Care Med. 2013;187:A2435.

43. Decramer M, Anzueto A, Kerwin E, et al. Efficacy and safety of umeclidinium plus vilanterol versus tiotropium, vilanterol, or umeclidinium monotherapies over 24 weeks in patients with chronic obstructive pulmonary disease: results from two multicentre, blinded, randomised controlled trials. Lancet Respir Med. 2014;2(6):472-486.

44. clinicaltrials.gov [homepage on the Internet]. DB2113374: a multicenter trial comparing the efficacy and safety of GSK573719/GW642444 with GSK 573719 and with tiotropium over 24 weeks in subjects with chronic obstructive pulmonary disease (COPD). ClinicalTrials.gov identifier NCT01316913; 2011 [updated January 9, 2014]. Available from: http:// clinicaltrials.gov/show/NCT01316913. Accessed May 18, 2014.

45. clinicaltrials.gov [homepage on the Internet]. A 52 week, multi-centre, open-label study to evaluate the safety and tolerability of GSK573719/ GW642444 125 mcg once-daily in combination with GW642444 25 mcg once-daily via novel dry powder inhaler (nDPI) in Japanese subjects with chronic obstructive pulmonary disease. ClinicalTrials.gov identifier NCT01376388; 2011 [updated February 13, 2014]. Available from: http://clinicaltrials.gov/show/NCT01376388. Accessed May 18, 2014.
46. FDA Advisory Committee Briefing Document. ANOROTM ELLIPTA ${ }^{\mathrm{TM}}$ (Umeclidinium Bromide/Vilanterol Inhalation Powder) For Treatment of Chronic Obstructive Pulmonary Disease. Available from: http://www.fda. gov/downloads/AdvisoryCommittees/CommitteesMeetingMaterials/ Drugs/Pulmonary-AllergyDrugsAdvisoryCommittee/UCM367414. pdf. Accessed May 28, 2014.

47. Prakash A, Babu KS, Morjaria JB. Novel anti-cholinergics in COPD. Drug Discov Today. 2013;18(21-22):1117-1126.

48. Cazzola M, Segreti A, Matera MG. New developments in the combination treatment of COPD: focus on umeclidinium/vilanterol. Drug Des Devel Ther. 2013;7:1201-1208.

49. Feldman GJ, Edin A. The combination of umeclidinium bromide and vilanterol in the management of chronic obstructive pulmonary disease: current evidence and future prospects. Ther Adv Respir Dis. 2013;7(6):311-319.

\section{Publish your work in this journal}

The International Journal of COPD is an international, peer-reviewed journal of therapeutics and pharmacology focusing on concise rapid reporting of clinical studies and reviews in COPD. Special focus is given to the pathophysiological processes underlying the disease, intervention programs, patient focused education, and self management protocols.

\section{Dovepress}

This journal is indexed on PubMed Central, MedLine and CAS. The manuscript management system is completely online and includes a very quick and fair peer-review system, which is all easy to use. Visit http://www.dovepress.com/testimonials.php to read real quotes from published authors. 